Full length article

\title{
Risk factors for sporadic norovirus infection: A systematic review and meta-analysis
}

\author{
Anne Thébault ${ }^{\mathrm{a}, *}$, Julie David ${ }^{\mathrm{b}}$, Pauline Kooh ${ }^{\mathrm{a}}$, Vasco Cadavez ${ }^{\mathrm{c}}$, Ursula Gonzales-Barron ${ }^{\mathrm{c}}$, \\ Nicole Pavio ${ }^{\mathrm{d}}$ \\ ${ }^{a}$ Risk assessment Department, French Agency for Food, Environmental and Occupational Health and Safety (ANSES), Maisons-Alfort, France \\ ${ }^{\mathrm{b}}$ ANSES, Ploufragan-Plouzané laboratory, Ploufragan, France

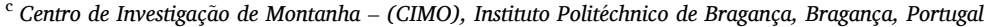 \\ d ANSES, Animal Health Laboratory, UMR 1161 Virologie INRA, Enva, Maisons-Alfort, France
}

\section{A R T I C L E I N F O}

\section{Keywords:}

Research synthesis

Meta-regression

Case-control studies

Norovirus

Odds-ratio

\begin{abstract}
A B S T R A C T
Norovirus is responsible for $20 \%$ of acute gastroenteritis worldwide. The fecal-oral route of transmission is known, but we proposed a first attempt to identify the relative importance of different sources and vehicles for sporadic cases using meta-analysis models. Case-control and cohort/cross-sectional studies were systematically reviewed and analyzed to assess the main risk factors associated with sporadic norovirus infections. Suitable scientific articles were identified through systematic literature search and subjected to a methodological quality assessment. Mixed-effects meta-analyses models were adjusted by population type to appropriate risk factor categories. The quality assessment stage led to include 14 primary studies conducted between 1993 and 2014. From these, eight studies investigated exposures in children/infants, and eight concerned the mixed population.

The meta-analysis confirmed the oro-fecal route for norovirus infections, with the person-to-person transmission (pooled $\mathrm{OR}=3.002$; 95\% CI: [2.502-3.062] in mixed population), and the lack of personal hygiene (pooled $\mathrm{OR}=2.329 ; 95 \% \mathrm{CI}$ : [1.049-5.169]). The meta-analysis also enlightened the role of indirect transmission through the environment with pathways like untreated drinking water (mixed population), with a pooled $\mathrm{OR}=2.680$ (95\% CI: [1.081-6.643]) and farm environment (children population). Indirect transmission also involved the food pathway, which was finally found significant with consumption of seafood (mixed population) (pooled $\mathrm{OR}=2.270 ; 95 \% \mathrm{CI}$ : [1.299-3.968]) and composite food (eating outside/uncooked mixed and young population) (pooled $\mathrm{OR}=4.541 ; 95 \% \mathrm{CI}$ : [3.461-5.958]).

These results are coherent with the findings from studies on outbreaks. However, a too broad definition of exposure factors limited the interpretation of results, as occurred with the seafood pathways that combined fish and shellfish. Other factors such as consumption of Food-handled products or the type of drinking water deserveE to be better investigated. Furthermore, better harmonization in case definition and appropriate case-control or cross-sectional studies would allow better addressing sporadic cases risk factors, especially for susceptible populations, such as children, elderly or immunosuppressed persons.
\end{abstract}

\section{Introduction}

Norovirus is estimated to contribute to $20 \%$ acute gastroenteritis worldwide (Ahmed et al., 2014). In USA, Japan, and Europe, around $50 \%$ of all outbreaks of gastroenteritis are attributed to norovirus (Patel et al., 2009). The peak of norovirus disease outbreaks usually occurs in temperate developed countries during wintertime (Mounts et al., 2000).

Norovirus infection is characterized by a short incubation of 24-48 hours (Karst et al., 2010). Symptoms usually described are sudden onset of severe vomiting (originally called "winter vomiting disease"), abdominal cramps, myalgia, and non-bloody-diarrhea, usually resolving in 2-3 days (Karst et al., 2010). In high-risk groups such as young children, elderly, and immunodeficient people, severe symptoms can lead to dehydration and hospitalization or even death (Karst, 2010; Verhoef et al., 2013; Green et al., 2014). Among patients hospitalized for severe gastroenteritis, norovirus infections account for around $12 \%$ of cases

\footnotetext{
* Corresponding author.

E-mail address: anne.thebault@anses.fr (A. Thébault).
} 
among children below 5 years old. It is the second cause of endemic diarrhea in children worldwide after rotavirus infections (Patel et al., 2009).

The norovirus genus belongs to the Caliciviridae family. This genus is divided into ten genogroups (GI to GX) and 49 genotypes (Chhabra et al. 2019). Norovirus can infect humans and mammalian animals, but no zoonotic transmission has been described (De Graaf et al.,2016). Within each genogroup, different genotypes are described and can be subdivided into strains or variants. Novel variants emerge periodically, such as GII. 4 (Sydney) or GII.7 (Atmar et al., 2018). The mutation rate is high, and the diversity of strains is of importance for explaining escaping immunity and regular epidemics in human populations (Dingle et al., 2004; Lindesmith et al., 2008; Bull et al., 2010). Humans are the reservoir for human norovirus strains. During outbreaks, common routes of transmission are person-to-person contact and food contaminated by infectious food-handlers, such as ready-to-eat foods that require human handling, and that are consumed without further cooking (Guix et al., 2019). Different food products were also identified as the origin of outbreaks after indirect contamination with human fecal matter. For example, shellfish harvested in marine contaminated waters (Maalouf et al., 2010) and vegetables, soft fruit such as raspberries or leafy greens (salads) irrigated with water contaminated by sewage (Muller et al,
2016; Tavoshi et al., 2015).

Methods for norovirus genome detection are available for clinical and environmental samples, such as water, or food, like shellfish. Protocols using molecular tools have been developed (RT-PCR, real-time RT-PCR and digital-real time RT-PCR) (Polo et al., 2016), but these rapid and accurate diagnostic assays remain costly for developing countries. Besides, molecular tools are not able to differentiate between infectious and non-infectious viruses, even now that a new approach to solve this issue is promising (Manuel et al., 2018; Chan et al., 2019).

Risk attribution for sporadic cases of norovirus infection remains a challenge by risk assessment approach -due to uncertain estimates of infectious viral contamination, and epidemiological data appear more reliable. Given the globalization of the food chain, it is important to investigate sporadic cases at a global scale. Hence, the objective of this study was to assess risk factors for norovirus sporadic infection by systematic review and meta-analysis of case-control studies, regardless of the country of origin. However geographical differences, if detected, can be further analyzed and discussed.

\section{Material and methods}

To determine the main risk factors for sporadic norovirus cases,

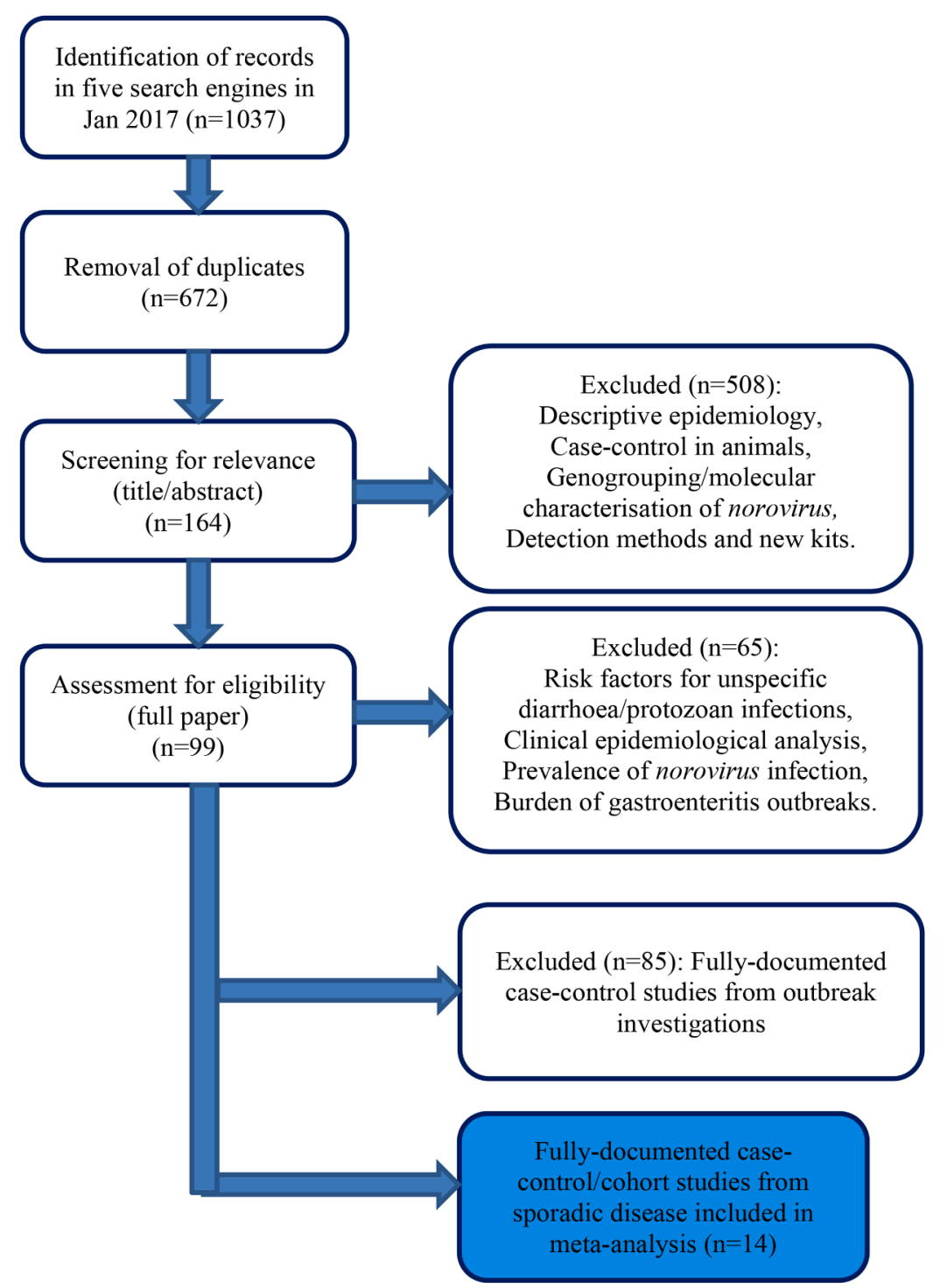

Fig. 1. PRISMA Flow chart of literature search for case-control and cohort studies of human norovirus infection 
relevant scientific information contained in epidemiologic case-control and cross-sectional/cohort studies publications has been systematically reviewed. The protocol of the systematic review and the metaanalysis model are described in depth in the methodological article of this special issue (Gonzales-Barron et al., 2019).

\subsection{Systematic review}

The Literature search was conducted from March 2017 to December 2017 using a combination of keywords related to (1) Norovirus OR Norwalk, (2) case-control OR risk factor OR cohort, and (3) infection OR disease, joined by the logical connector AND. Relevant studies were identified from five bibliographic search engines, Science Direct, PubMed, Scielo, ISI Web of Science and Scopus. . The search was limited to the languages English, French, Portuguese and Spanish. No restrictions were defined for the year of the study or type of publication. Each reference record was screened for relevance for inclusion in the meta-analysis study, and subsequently, the methodological quality of the "candidate" studies were assessed using pre-set quality criteria comprising (1) appropriate selection of the controls; (2) adjustment to correct for confounders, (3) comparability between cases and controls, (4) acceptable responses rates for the exposed and control groups; (5) Data analysis appropriate to the study design; (6) provision of OddsRatio (OR) with confidence interval or p-value; or provision of sufficient data to calculate ORs; (7) overall quality of the study (Gonzales-Barron et al., 2019).

Primary studies that passed the screening for relevance were marked as having potential for bias if they failed to meet at least one of the methodological quality assessment criteria (Table 1 ). Data from primary studies were then extracted using a standardised spreadsheet. Data extracted included the relevant study characteristics (location, time period, population, case definition, design, sample size of the groups, type of model, etc.), the risk factors, the setting, the handling practices and the outcome of the study (OR).

\subsection{Data synthesis}

The joint meta-analytical dataset was first described using basic statistics. Next, data was partitioned into subsets of categories of risk factors: travel, host-specific factors and transmission pathways related to person-to-person contagion, animal contact, environmental exposures and food vehicles. The variable "population" was stratified into mixed (adults or undefined) and children (at least under 16 years old). Metaanalysis models were fitted by meta-regression to each subset of categories (i.g travel), with subgroup class that depends of data partition (i. g. abroad, inside). The meta-analytical models were fitted separately by population type. The statistical analysis was designed to assess the effect of the geographical region. The objective of the region-specific metaanalysis was to inform the decision on the geographical regions that should be kept for the subsequent pooling of ORs. A Geographical region (Asia, North America, South America, Africa, Europe, Oceania) was removed from a particular meta-analysis partition only if its pooled ORs were different from those associated with the other regions or if less than 3 ORs represented the region (Gonzales-Barron et al., 2019). The situation of exclusion of a particular region never occured for norovirus, because no strong heterogeneity between regions could be detected (when this analysis was feasible).

Even if no heterogeneity between regions was detected, meta-

Table 1

Characteristics of primary studies investigating risk factors for acquiring sporadic norovirus infection included in the meta-analysis.

\begin{tabular}{|c|c|c|c|c|c|c|c|}
\hline Study ID & Country & Study period & Population & Design & $\begin{array}{l}\text { Analysis \& } \\
\text { model }^{* *}\end{array}$ & $\begin{array}{l}\text { \# cases } \\
\text { /controls }\end{array}$ & $\begin{array}{l}\text { Potential for bias in meta-analysis }{ }^{* * *} \text { Final } \\
\text { ORs/removed } *\end{array}$ \\
\hline Dai et al. 2010 & China & $\begin{array}{l}\text { Oct } 2003-\text { Jan } \\
2006\end{array}$ & Children & Matched & $\begin{array}{l}\text { Uni-UL } \\
\text { Multi-UL }\end{array}$ & $\begin{array}{l}112 \text { cases } \\
357 \text { controls }\end{array}$ & $\begin{array}{l}\text { No } \\
8\end{array}$ \\
\hline Enserink et al.2015 & Netherlands & $2010-2012$ & Children & Unmatched & Multi-UL & $\begin{array}{l}504 \text { cases } \\
4693 \text { controls }\end{array}$ & $\begin{array}{l}\text { Yes } \\
3\end{array}$ \\
\hline Fretz et al. 2005 & Switzerland & $2001-2003$ & Mixed & Matched & Uni- CL & $\begin{array}{l}73 \text { cases } \\
73 \text { controls }\end{array}$ & $\begin{array}{l}\text { No } \\
5\end{array}$ \\
\hline Grant et al. 2012 & USA & $\begin{array}{l}\text { Mar } 2002 \text { - Oct } \\
2003\end{array}$ & Children & Unmatched & Multi-UL & $\begin{array}{l}62 \text { cases } \\
50 \text { controls }\end{array}$ & $\begin{array}{l}\text { No } \\
1\end{array}$ \\
\hline $\begin{array}{l}\text { Henke-Gendo et al. } \\
2009\end{array}$ & Germany & $\begin{array}{l}\text { Jan } 2005- \\
\text { Jun } 2008\end{array}$ & Mixed & Unmatched & $\begin{array}{l}\text { Uni-Chi } \\
\text { Multi-UL }\end{array}$ & $\begin{array}{l}20 \text { cases } \\
58 \text { controls }\end{array}$ & $\begin{array}{l}\text { Yes } \\
6\end{array}$ \\
\hline $\begin{array}{l}\text { Heusinkveld et al. } \\
2016\end{array}$ & Netherlands & $\begin{array}{l}\text { Apr } 2013- \\
\text { Oct } 2014\end{array}$ & $\begin{array}{l}\text { Children \& } \\
\text { adult }\end{array}$ & Unmatched & Multi-UL & $\begin{array}{l}60 \text { cases } \\
1843 \text { controls }\end{array}$ & $\begin{array}{l}\text { No } \\
6\end{array}$ \\
\hline Karsten et al. 2009 & Germany & Jan - Dec 2004 & Mixed & Unmatched & Multi-UL & $\begin{array}{l}186 \text { cases } \\
1399 \text { controls }\end{array}$ & $\begin{array}{l}\text { No } \\
2\end{array}$ \\
\hline My et al. 2013 & Vietnam & $\begin{array}{l}\text { May } 2009-\text { Dec } \\
2010\end{array}$ & Children & Unmatched & $\begin{array}{l}\text { Uni-Chi } \\
\text { Multi-UL }\end{array}$ & $\begin{array}{l}242 \text { cases } \\
592 \text { controls }\end{array}$ & $\begin{array}{l}\text { No } \\
13\end{array}$ \\
\hline Peasey et al. 2004 & Mexico & $\begin{array}{l}\text { Nov } 1993 \text { - Jan } \\
1995\end{array}$ & Children & Unmatched & $\begin{array}{l}\text { Uni-Chi } \\
\text { Uni-UL }\end{array}$ & $\begin{array}{l}83 \text { cases } \\
174 \text { controls }\end{array}$ & $\begin{array}{l}\text { No } \\
9\end{array}$ \\
\hline Phillips et al. 2010a & UK & $1993-1996$ & $\begin{array}{l}\text { Children } \\
\text { Mixed }\end{array}$ & Matched & Multi-UL & $\begin{array}{l}81 \text { cases } \\
461 \text { controls } \\
156 \text { cases } \\
1206 \text { controls }\end{array}$ & $\begin{array}{l}\text { No } \\
19\end{array}$ \\
\hline Relic et al. 2015 & Serbia & $2010-2011$ & Mixed & Unmatched & Uni-Chi & $\begin{array}{l}36 \text { cases } \\
51 \text { controls }\end{array}$ & $\begin{array}{l}\text { No } \\
1\end{array}$ \\
\hline Tang et.al 2013 & Taiwan & $\begin{array}{l}\text { Aug } 2011-\text { Jul } \\
2012\end{array}$ & Mixed & Unmatched & Uni-Chi & $\begin{array}{l}17 \text { cases } \\
138 \text { controls }\end{array}$ & $\begin{array}{l}\text { No } \\
2\end{array}$ \\
\hline De Wit et al. 2003 & Netherlands & 1999 & $\begin{array}{l}\text { Mixed } \\
\text { Children }\end{array}$ & Matched & $\begin{array}{l}\text { Uni-Chi } \\
\text { Multi-CL } \\
\text { Uni-Chi } \\
\text { Multi-CL }\end{array}$ & $\begin{array}{l}152 \text { cases } \\
152 \text { controls } \\
105 \text { cases } \\
105 \text { controls }\end{array}$ & $\begin{array}{l}\text { No } \\
26\end{array}$ \\
\hline Xue et al. 2015 & China & $\begin{array}{l}\text { May } 2012 \text { - Aug } \\
2013\end{array}$ & Mixed & Unmatched & Uni-Chi & $\begin{array}{l}903 \text { cases } \\
3038 \text { controls }\end{array}$ & $\begin{array}{l}\text { No } \\
1\end{array}$ \\
\hline
\end{tabular}

\footnotetext{
* Number of ORs not included in the meta-analysis for presenting mean values lower than 0.5.

** Uni-Chi: univariate Analysis with Chi-square; Uni-UL: univariate analysis with Unconditional Logistic regression; Multi-CL: multivariate analysis with conditional logistic regression; Multi-UL: multivariate analysis with unconditional logistic regression

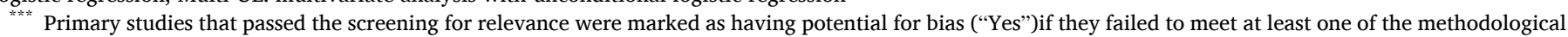
quality assessment criteria: details in "systematic review" and "descriptive statistics section".
} 
analytical forest plots constructed for all risk factors provided information about heterogeneity between studies, the precise risk factor label applied in each study and in particular the period and country of origin of the study.

All meta-analysis models were essentially weighted random-effects linear regression models.

Once a meta-analysis model was fitted, influential diagnostics statistics were assessed in order to remove any influential observation originating from studies marked as having potential-for-bias. Publication bias was assessed by funnel plots, exploring the relationship between the observed outcome (or residuals of the model with moderators) and their corresponding inverse standard error (Gonzales-Barron et al., 2019).

Next, a statistical test investigated the effect of the study's sample size on the ORs, which is expected to be non significant (Table 3) (Gonzales-Barron et al., 2019). Heterogeneity between studies was assessed by different indicators such as the between-study variability $\left(\tau^{2}\right)$, the QE test investigating residual heterogeneity, the variance of residuals and the intra-class correlation $\mathrm{I}^{2}$ (Gonzales-Barron et al., 2019).

All analyses were produced using the $\mathrm{R}$ software ( $\mathrm{R}$ Development Core Team, 2008) implemented with the metafor package (Viechtbauer, 2010). The meta-analyzed risk factors are presented in Table 3 only when significant. Pooled ORs were considered as significant when the lower bound of the $95 \% \mathrm{CI}$ was equal or greater than 1 . Whenever a category is s not significant, the result is given in Table 4 .

\section{Results}

\subsection{Descriptive statistics}

In the systematic review of risk factors pertaining to human infection with norovirus, a total of 672 bibliographic sources were identified using the keywords in the five search engines, from which 99 passed the full assessment for eligibility, comprising case-control,cross-sectional and cohort studies from both sporadic illnesses and outbreaks (Fig. 1). Eighty-five fully-documented case-control studies investigated the source(s) of outbreaks and were excluded. The overall exclusion process is described in the methodological paper (Gonzalez-Barron et al., 2019). Meta-analysis was undertaken using 14 primary studies - case-control, cross-sectional and cohort studies - with focus on sporadic disease, conducted between 1993 and 2013 (Table 1). Among those 14, 6 studies were done after 2009, 11 after 2000, and by decreasing order they come from Western Europe (6), Asia (4) and the other ones from another part of Europe (2), North America (1) and Latin America (1). The eligible studies jointly provided 102 ORs associated with risk factors that were categorized for meta-analysis. A total of 54 ORs were retrieved from 3 case-control studies performed before the year 2000, while 48 ORs were extracted from 11 studies performed after 2000. Meta-analytical data were obtained from studies conducted in 10 countries: $83 \%$ of the ORs originate from 5 countries only, the Netherlands (35 ORs), UK (19 ORs), Vietnam (13 ORs), China ( 9 ORs) and Mexico ( 9 ORs). Ten primary studies employed an unmatched experimental design, from them 3 did not adjust ORs by any confounder (i.e., crude ORs by Chi-square test), while the others were adjusted for other factors, using unconditional logistic regression. Four studies employed a matched experimental design. Most of them were adjusted ORs estimated by logistic regressions (Table 1).

The population is divided in adults or mixed population (50 ORs in 9 publications) and children (52 ORs in 8 publications) (Table 1). Risk factors categories studied were, in decreasing order, transmission from person-to-person (38 ORs) (e.g. contacts with person with diarrhea), food ( 28 ORs) (e.g. eating shelffish), environment (18 ORs)(e.g. living in rural residence, drinking well water), host specific (hygiene included) (9 ORs)(e.g. immunosuppression), contact with animals (7 ORs) (e.g. contact with pets, livestock or poultry) and travel (2 ORs). Two publications had potential bias (Table 1): in Enserink et al (2015), the publication gives estimated IRR (incidence rate ratios) that were assumed to be close to OR ( 3 ORs in the category environment). The second one addresses cases with prolonged norovirus excretion $(>10$ days) in comparison of cases with short excretion (Henke-Jendo, 2009) (6 ORs concerning different host factors). Few papers mentioned clearly the genogroup (6 papers), some of them mentioned mixed genogroups (GI/GII) (3), 1 GI or GII and 3 genogroup GII.4. No particular link between genogroups and risk factors could be evidenced.

Even if the definition of case of acute gastroenteritis associated with norovirus infection was slightly different between studies either in the definition of the controls or in the detection method, all of them were included. For some studies, the ORs were based only on norovirus detection (Table 2), while, in others, the definition included acute gastroenteritis with evidence of norovirus infection. This discrepancy was also described in the meta-analysis by Ahmed et al. (2014). We assumed that risk factors of infection could be extrapolated to norovirus gastroenteritis. The criteria for cases recruitment were various, ranging from recruitment at hospitals to the general population (Table 2), therefore probably including different severity of cases or age for children (Table 2). We assumed that the severity of the disease did not influence the significance of risk factors.

\subsection{Meta-analysis results}

All significant results are given in Table 3. Travel exposure could not be included in the meta-analysis due to scarcity of data (2 ORs extracted from one study in England: Phillips et al., 2010a). In this study, international travel was evaluated as risk factor for acquiring norovirus infection in both children and mixed population. Likely, host-specific factors, such as suffering from a chronic disease (e.g., immunosuppression) or another medical condition (e.g., being a transplant recipient), were investigated in only one study with 6 ORs (Henke-Gendo, 2009), and hence, they were excluded from the meta-analysis.

The contact, at home or outside home, with an ill person suspected or known to have norovirus was studied in 6 publications ( 38 ORs). Adults who have contact with infected persons, within or outside the household, presented a pooled OR of 3.002 (95\% CI: [2.502-3.602]; Table 3). The pooled OR of person-to-person transmission for children was also significant (pooled $\mathrm{OR}=4.648$; 95\% CI: [2.092-10.325]), and higher than that of the mixed population. The details of the ORs for person-toperson transmission in log scale are given in Fig. 2 for children, and in Fig. 3 for mixed population. Diversity of contacts with ill person or household members with gastroenteritis, or vomiting, is described inside household, or outside (Figs. 2 and 3). Lack of handwashing (after toilets) was studied in children and was shown to be a significant with a pooled OR=2.329 (95\% CI: [1.049-5.169]), but with only 2 ORs from 2 publications.

The environmental pathways in mixed population included farm environment, attendance to daycare center, and drinking water. The first two routes could not be analyzed since they only consisted of only one OR each. Drinking water was not found significant in the mixed population with a pooled $\mathrm{OR}=1.753$ (95\% CI: [0.969-3.171]; Table 4). Nonetheless, excluding 2 ORs coming from "tap water", therefore restricting analysis to non-treated drinking water such as "local water supply" and "spring water", produced a significant pooled OR of 2.680 (95\% CI: [1.081-6.643]).

For children, attending daycare ( 2 publications, 3 OR) was not found significant with one publication from Vietnam (lower OR) and the other one from the Netherlands (higher ORs). Drinking water from wells or other sources was not found significant in children, though the information was very limited (1 publication from My et al, 2013 with 4 ORs). Playing in a padding pool or sandpit was only represented by one OR, and was hence removed from the analysis. The children population exposed to rural living conditions (living on a farm) clearly showed a significant pooled OR (1.563; 95\% CI: [1.082-2.257]). Contact with 
Table 2

Characteristics of primary studies investigating risk factors for acquiring sporadic norovirus infection included in the meta-analysis in term of definition of cases/control and recruitment of cases.

\begin{tabular}{|c|c|c|}
\hline Study ID & $\begin{array}{l}\text { Definition infection or case \& } \\
\text { infection / control }\end{array}$ & Recruitment of cases \\
\hline Dai et al. 2010 & $\begin{array}{l}\text { AcGE+positive RT-PCR / AcGE } \\
\text { negative RT-PCR+Rotavirus PCR } \\
\text { positive }\end{array}$ & Hospital \\
\hline $\begin{array}{l}\text { Enserink et al. } \\
2015\end{array}$ & $\begin{array}{l}\text { Nov Positive with real time } \\
\text { multiplex PCR assays/Nov negative }\end{array}$ & Day Care Centers \\
\hline Fretz et al. 2005 & $\begin{array}{l}\text { AcGE+positive RT-PCR+negative } \\
\text { other pathogens/ no AcGE }\end{array}$ & $\begin{array}{l}\text { General practitioner } \\
\text { based }\end{array}$ \\
\hline $\begin{array}{l}\text { Grant et al. } \\
2012\end{array}$ & $\begin{array}{l}\text { AcGE + norovirus rRT-PCR positive/ } \\
\text { negative }\end{array}$ & $\begin{array}{l}\text { Placebo group of oral } \\
\text { PRV Rota Teq vaccine; } \\
\text { children below } 9 \\
\text { months old }\end{array}$ \\
\hline $\begin{array}{l}\text { Henke-Gendo } \\
\text { et al. } 2009\end{array}$ & $\begin{array}{l}\text { rRT-PCR positive after } 10 \text { days/rRT- } \\
\text { PCR positive not after } 10 \text { days }\end{array}$ & Hospitals \\
\hline $\begin{array}{l}\text { Heusinkveld } \\
\text { et al. } 2016\end{array}$ & $\begin{array}{l}\text { Multiplex RT-PCR positive/ RT-PCR } \\
\text { negative }\end{array}$ & $\begin{array}{l}\text { Preschool children from } \\
\text { population registries }\end{array}$ \\
\hline $\begin{array}{l}\text { Karsten et al. } \\
2009\end{array}$ & $\begin{array}{l}\text { Positive with nested RT-PCR \& } \\
\text { AcGE/negative with nested RT-PCR }\end{array}$ & physicians \\
\hline My et al. 2013 & $\begin{array}{l}\text { RT-PCR positive\& AcGE / negative } \\
\text { and no AcGE }\end{array}$ & Hospitals \\
\hline $\begin{array}{l}\text { Peasey et al. } \\
2004\end{array}$ & Elisa positive/Elisa negative & $\begin{array}{l}\text { Random samples of } \\
\text { household }\end{array}$ \\
\hline $\begin{array}{l}\text { Phillips et al. } \\
\text { 2010a }\end{array}$ & $\begin{array}{l}\text { AcGE with rRT-PCR positive for GII } \\
\text { and RT-PCR for GI+electron } \\
\text { microscopy / norovirus negative } \\
\text { control+without GE symptoms }\end{array}$ & $\begin{array}{l}\text { Cohort in community \& } \\
\text { general practitioner }\end{array}$ \\
\hline Relic et al. 2015 & $\begin{array}{l}\text { AcGE+positive with } \\
\text { immunochromatography assay/ } \\
\text { control =AcGE + negative } \\
\text { immunochromatography }\end{array}$ & $\begin{array}{l}\text { Microbiology laboratory } \\
\text { of Public health }\end{array}$ \\
\hline Tang et.al 2013 & $\begin{array}{l}\text { AcGE+RT-PCR positive/ RT-PCR } \\
\text { negative } \\
\text { noAcGE+RT-PCR positive/ } \\
\text { noAcGE+RT-PCR negative }\end{array}$ & Hospital \\
\hline $\begin{array}{l}\text { De Wit et al. } \\
2003\end{array}$ & RT-PCR positive+AcGE/ no AcGE & Community cohort \\
\hline Xue et al. 2015 & $\begin{array}{l}\text { AcGE + Positive with rRT-PCR/ } \\
\text { AcGE + negative rRT-PCR }\end{array}$ & Hospitals \\
\hline
\end{tabular}

Legend: AcGE: acute gastroenteritis, RT-PCR: Reverse Transcription Polymerase Chain Reaction; rRT-PCR Real Time Reverse Transcription Polymerase Chain Reaction

animals (cats, dog, bird, livestock,) was studied as a potential route in five publications ( 7 ORs) for both mixed and children population, but it was not found to be a significant factor (pooled $\mathrm{OR}=1.199 ; 95 \% \mathrm{CI}$ : [0.557-2.577]).

For the mixed population, different food products were scrutinized in several papers ( 8 ORs in 4 publications), such as vegetables ( 2 ORs), mineral water (1 OR), sweet beverages (1 OR), shellfish (2 ORs), fish (1 OR) or "suspicious food" (1 OR). Due to the low number of ORs in each category, only 3 subcategories were investigated. While seafood was found significant (OR=2.270; 95\% CI: [1.299-3.968] in Table 3), neither beverages ( 1 publication, Fretz (2005)) nor crop produces (1 publication, Fretz (2005)) were found significant and hereafter could not be proven as important vehicles for norovirus transmission. For seafood, it is worth mentioning that in the UK the consumption of oysters $(\mathrm{OR}=18.30 ; 95 \% \mathrm{CI}:[1.50-226.6])$ and whelks and winkles $(\mathrm{OR}=20.50$; 95\% CI: $[1.60-265.7])$ bore higher risk of disease than the consumption of fish in the Netherlands $(\mathrm{OR}=1.80$; 95\% CI: $[1.00$ 3.20]).

For children, 14 ORs in 3 publications describe different food items (Dai et al., 2010; My et al., 2013; Peasey et al., 2004). In China and Vietnam, data were available about consumptions in market food (2 ORs), eating outside (1 OR), uncooked food (2 ORs), seafood (1 OR), bottled water ( 2 ORs). In Mexico, different ways of chicken or meat consumption were investigated ( $6 \mathrm{ORs}$ ). Then, two categories of food products could be investigated: composite food and meat. Consumption of composite food was found highly significant $(\mathrm{OR}=4.541 ; 95 \% \mathrm{CI}$ : [3.461-5.958]). However, this category is heterogeneous with details given in Fig. 4. In any case, it can be observed that eating uncooked, outside, or in market food can be at risk for children consumers in China and Vietnam. For meat, all ORs came from the same publication (Peasey et al., 2004), and the pooled OR was not found significant.

For all the meta-analytical models reported in Table 3, the statistical tests indicated the presence of potential significant publication bias below $5 \%$, with exception of no handwashing, person-to-person transmission, and environment and food in children. For better assessing the publication bias, the funnel plots for models with significant publication bias are given in Fig. 5. "No handwashing" has too few ORs to be taken into consideration. For "person-to-person" and "environment" in children population, there was an asymmetry towards lack of small studies with smaller ORs. Furthermore, since there were very few ORs for food products in the mixed population, an overall trend in the funnel plot is not obvious and is probably linked to the heterogeneity in the different kind of food products in this category. Moreover, the intra-class correlation, as percentage of the total variance that is explained by the variation between studies, "I ${ }^{2}$ ", was always below high heterogeneity $(<75 \%)$ (Table 1). Most often, remaining between-study heterogeneity (significant p-val below 0.05 for $\mathrm{Q}$ or $\mathrm{QE}$ ) was not observed for the data partitions, except for person-to-person transmission.

\section{Discussion}

The main results of this meta-analysis on norovirus sporadic cases support the importance of the global feco-oral pathway for norovirus transmission. Person-to-person contact was identified as the major risk factor, involving mechanical transmission from environmental surfaces, hand contacts or vomit aerosols. Outbreaks data are in line with these results, since they have been described in closed environments, such as elementary schools, hospitals, day-care centers, cruise ships or military settings, and are favored by person-to-person contact, either direct or secondary (Ho et al., 1989; Loury et al., 2015; Sukrie et al., 2012; Patel, 2009; Karst, 2010). Lack of hygiene, namely "no handwashing after using the toilet", was found to be a significant risk factor in this meta-analysis, probably linked to an indirect inter-human transmission. Washing hands before cooking or after attending public places, as studied in Arena et al. (2014) could not be studied for norovirus sporadic cases.

Environmental factors could not be meta-analyzed properly because of irrelevant subcategories or the insufficient number of studies and ORs. Untreated drinking water was found significant, yet with only 2 ORs. This result is in agreement with described waterborne outbreaks most often associated with multiple strains of norovirus (Matthews et al., 2012). Surprisingly, attendance at a daycare center (but with only two publications in children) remained not significant, even if frequently associated with outbreaks. Using public transportation could not be studied. Furthermore, host-specific factors, such as immunosuppressive treatment or other medical conditions, could not be studied due to data scarcity. For the food categories, it can be observed that the significant pooled OR for eating uncooked, outside, or in a food market can be the consequence of poor food handling practices by the caterer or even unwashed hands before having the meal. However this result was only investigated in China and Vietnam. In this respect, outbreaks due to food handlers are regularly investigated (De Wit et al., 2007; Hardstaff et al., 2018).

Seafood was found significant in the mixed population, yet there was not enough data to distinguish shellfish from other seafood, and in particular raw oysters consumption from other seafood. Oysters have been regularly contaminated and involved in outbreaks in France and Europe (Le Guyader et al. 2010, Schaeffer et al. 2013, Lowther et al. 2012) but not fish or crustaceans. Furthermore, other food products shown to be responsible for outbreaks (for instance, soft fruits) were not included in the meta-analysis (Made et al. 2013, Le Guyader et al. 2004), 
Table 3

Significant results of the meta-analysis on main risk factors for norovirus infection.

\begin{tabular}{|c|c|c|c|c|c|c|c|}
\hline Population & Risk factor & $\begin{array}{l}\text { Pooled OR } \\
\text { [IC95\%] }\end{array}$ & $\underset{*}{\mathrm{~N} / \mathrm{n}}$ & $\begin{array}{l}\mathrm{p} \text {-value of risk } \\
\text { factor }\end{array}$ & $\begin{array}{l}\text { Publica-tion bias p- } \\
\text { value }\end{array}$ & $\begin{array}{l}\text { Points } \\
\text { removed } * *\end{array}$ & Heteroge-neity analysis ${ }^{* * *}$ \\
\hline \multicolumn{8}{|c|}{ Lack of hygiene } \\
\hline Children & No handwashing & $\begin{array}{l}2.329 \\
{[1.049-5.169]}\end{array}$ & $2 / 2$ & 0.0377 & 0.050 & 0 & $\begin{array}{l}\tau^{2}=0.154 \\
Q(d f=1)=3.846 ; p-v a l= \\
0.050 \\
\mathrm{~s}^{2}=0.844 \\
\mathrm{I}^{2}=15.455\end{array}$ \\
\hline \multicolumn{8}{|c|}{ Person to person by population } \\
\hline Mixed & & $\begin{array}{l}3.002 \\
{[2.502-3.602]}\end{array}$ & $\begin{array}{l}3 / \\
21\end{array}$ & $<.0001$ & 0.014 & 0 & $\begin{array}{l}\tau^{2}=0.774 \\
\mathrm{QE}(\mathrm{df}=36)=167.35 ; \mathrm{p} \text {-val }\end{array}$ \\
\hline Children & & $\begin{array}{l}4.648 \\
{[2.092-10.325]}\end{array}$ & $\begin{array}{l}5 / \\
17\end{array}$ & 0.0002 & & & $\begin{array}{l}<.0001 \\
\mathrm{~s}^{2}=0.876 \\
\mathrm{I}^{2}=46.912\end{array}$ \\
\hline \multicolumn{8}{|l|}{ Environment } \\
\hline Mixed & $\begin{array}{l}\text { Untreated drinking water (excluding } \\
\text { tap water) }\end{array}$ & $\begin{array}{l}2.680 \\
{[1.081-6.643]}\end{array}$ & $2 / 2$ & 0.0333 & 0.138 & 0 & $\begin{array}{l}\tau^{2}=0.029 \mathrm{~s}^{2}=0.890 \\
\mathrm{I}^{2}=3.198\end{array}$ \\
\hline Children & Farm & $\begin{array}{l}1.563 \\
{[1.082-2.257]}\end{array}$ & $3 / 3$ & 0.0172 & 0.013 & 0 & $\begin{array}{l}\tau^{2}=0.013 \\
Q E(d f=7)=12.960 ; p-v a l= \\
0.073 \\
\mathrm{~s}^{2}=0.136 \\
\mathrm{I}^{2}=8.969\end{array}$ \\
\hline \multicolumn{8}{|r|}{ 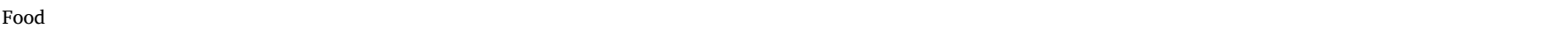 } \\
\hline Mixed & Seafood & $\begin{array}{l}2.270 \\
{[1.299-3.968]}\end{array}$ & $2 / 3$ & 0.0040 & 0.013 & 0 & $\begin{array}{l}\tau^{2}=0 \\
Q E(d f=4)=6.4028 ; p-v a l= \\
0.171 \\
\mathrm{~s}^{2}=1.187 \\
\mathrm{I}^{2}=0\end{array}$ \\
\hline Children & Composite food & $\begin{array}{l}4.541 \\
{[3.461-5.958]}\end{array}$ & $2 / 5$ & $<.0001$ & 0.108 & 0 & $\begin{array}{l}\tau^{2}=0 \\
\mathrm{QE}(\mathrm{df}=9)=5.4659 ; \mathrm{p}-\mathrm{val}= \\
0.7920 \\
\mathrm{~s}^{2}=0.131 ; \mathrm{I}^{2}=0\end{array}$ \\
\hline
\end{tabular}

${ }^{*} \mathrm{~N} / \mathrm{n}$ Number of studies/number of OR

** points removed by sensitivity analysis, all results are given after removing data concerned

${ }_{* * * *}^{*}$ Between-study variability $\left(\tau^{2}\right)$, test for residual heterogeneity $(\mathrm{QE})$, variance of residuals $\left(\mathrm{s}^{2}\right)$, intra-class correlation $\left(\mathrm{I}^{2}\right)$.

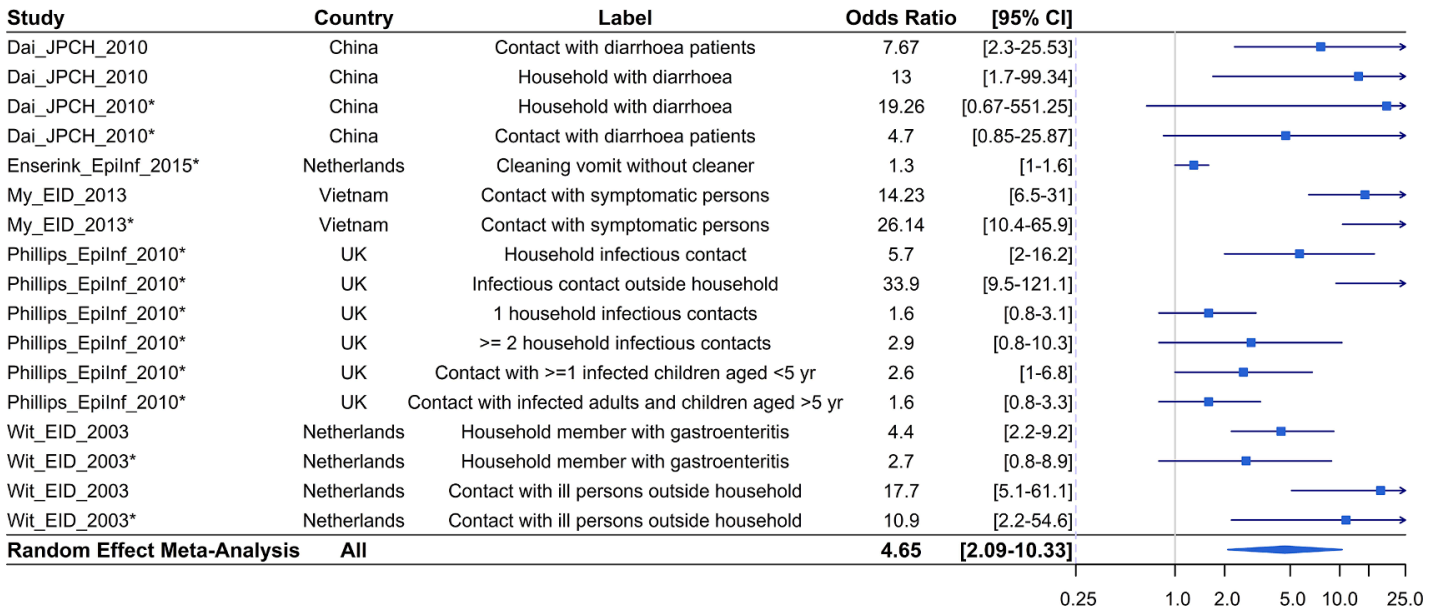

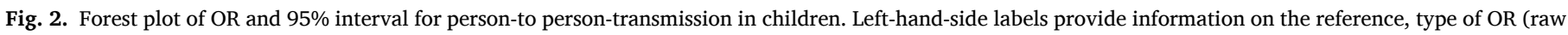
or * adjusted) and the exposure as mentioned in the reference

neither were drinking untreated water and recreational water (Boccia et al. 2002, Hoebe et al. 2004).

The number of publications (14) concerning risk factors of sporadic norovirus infection or norovirus gastroenteritis is low considering the disease burden in terms of morbidity. As an example, the community incidence of norovirus associated with infectious intestinal disease in the UK is estimated at around 4.5/100 person-years (Philipps et al., 2010b). In comparison with two other pathogens described in this meta-analysis issue, many more publications were eligible for Giardia (72 studies) and for hepatitis A virus (78 studies), which increased the power of the meta-analysis outcomes, and hence made it easier to identify risk factors associated to those pathogens. This is the main limitation of the present meta-analysis. A possible explanation is that outbreaks reports are numerous and used for source attribution (Mead et al., 1999; Matthews et al. 2012, Bitler et al. 2013, Verhoef et al. 2015). However, the extrapolation of results to sporadic cases is not so straightforward, because the population associated with outbreaks can be different from the general population, outbreaks can involve particular strains or doses, so that the ranking of risk factors could be different. Furthermore in The Netherlands, the annual number of cases involved in outbreaks (all sources) was estimated around $30 / 100,000$, whenever the incidence of community-acquired (sporadic) norovirus cases (all sources) 


\begin{tabular}{|c|c|c|c|c|}
\hline Study & Country & Label & Odds Ratio $[95 \% \mathrm{Cl}]$ & \\
\hline Karsten_EJCMID_2009* & Germany & Contact with persons with diarrhea & $2.7 \quad[1.44-5.07]$ & $\longrightarrow$ \\
\hline Phillips_Epilnf_2010* & UK & Children $<5 \mathrm{y} / \mathrm{o}$ in household & {$[1.6-4]$} & $\longrightarrow$ \\
\hline Phillips_Epilnf_2010* & UK & Baby wearing nappies in household & [1.8-4.6] & \\
\hline Phillips_Epilnf_2010* & UK & Household infectious contact & {$[2.7-8.8]$} & \\
\hline Phillips_Epilnf_2010* & UK & Infectious contact outside household & {$[2.5-8]$} & \\
\hline Phillips_Epilnf_2010* & UK & 1 household infectious contacts & {$[0.8-2.4]$} & \\
\hline Phillips_Epilnf_2010* & UK & $>=2$ household infectious contacts & {$[1.7-19.3]$} & \\
\hline Phillips_Epilnf_2010* & UK & Contact with $>=1$ infected children aged $<5 \mathrm{yr}$ & {$[1.9-9.6]$} & \\
\hline Phillips_Epilnf_2010* & UK & Contact with infected adults and children aged $>5 \mathrm{yr}$ & {$[0.8-1.6]$} & \\
\hline Wit_EID_2003 & Netherlands & s Household member to daycare center & {$[1-3.9]$} & \\
\hline Wit_EID_2003 & Netherlands & Household member to primary school & {$[1-2.7]$} & \\
\hline Wit_EID_2003 & Netherlands & 1 household members with gastroenteritis & {$[1.7-8]$} & \\
\hline Wit_EID_2003 & Netherlands & $>1$ household members with gastroenteritis & {$[3.9-34.7]$} & - \\
\hline Wit_EID_2003* & Netherlands & 1 household members with gastroenteritis & {$[0.3-4.2]$} & \\
\hline Wit_EID_2003* & Netherlands & $>1$ household members with gastroenteritis & {$[2-60.5]$} & \\
\hline Wit_EID_2003 & Netherlands & Contact with ill persons outside household & {$[4.7-27.3]$} & 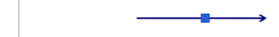 \\
\hline Wit_EID_2003* & Netherlands & Contact with ill persons outside household & {$[3.1-51.8]$} & $\longrightarrow$ \\
\hline Wit_EID_2003 & Netherlands & Household member with gastroenteritis & {$[2-113.6]$} & $\longrightarrow$ \\
\hline Wit_EID_2003* & Netherlands & Household member with gastroenteritis & {$[0.1-15.9] \leftarrow$} & \\
\hline Wit_EID_2003 & Netherlands & Contact with ill persons outside household & {$[1.7-20.1]$} & \\
\hline Wit_EID_2003* & Netherlands & Contact with ill persons outside household & {$[1-147.3]$} & \\
\hline Random Effect Meta-Analysis & s $\quad$ All & & [2.5-3.6] & - \\
\hline
\end{tabular}

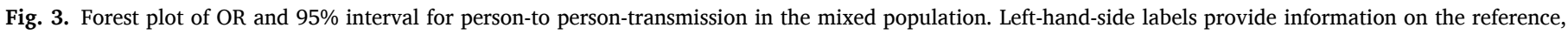
type of OR (raw or * adjusted) and the exposure as mentioned in the reference

Table 4

Non-significant risk factors (coming from non-isolated studies).

\begin{tabular}{llcc}
\hline Population & Risk factor & Pooled OR [IC95\%] & $\mathrm{N} / \mathrm{n}^{*}$ \\
\hline $\begin{array}{l}\text { Animals } \\
\text { All }\end{array}$ & Contact with animals & $1.199[0.557-2.577]$ & $5 / 7$ \\
Environment & & $1.753[0.969-3.171]$ & $3 / 4$ \\
Mixed & Drinking water & $1.342[0.946-1.902]$ & $2 / 3$ \\
Children & Daycare & $1.391[0.857-2.257]$ & $3 / 4$ \\
All & Daycare & & \\
\hline
\end{tabular}

* N/n Number of studies/number of OR

was around 3,800/100,000 (Verhoef et al., 2013). Even if outbreaks of small size can be under-detected, the relative part of outbreaks to the total burden of norovirus cases, base on the study in The Netherlands can be estimated to be very low, below $1 \%$.

In any case, the relative contribution of each source is not estimated most of the time in those sporadic case-control studies, with some rare exceptions like the estimation of PAR (population attributable risk fraction) in the publication of De Wit et al. (2003) and Phillips et al., 2010a. Some studies investigating risk factors of acute gastroenteritis without virus distinction (Arena et al., 2014) were not included in this meta-analysis. A harmonized definition of the acute case, associated with norovirus infection detection with proper control, checking for an existing immunity and an absence of asymptomatic infection, would reduce the extra source of variability between studies. However, for the last item, the risk of asymptomatic infection is limited: in a recent meta-analysis, it was estimated that asymptomatic infection prevalence is around $7 \%$ (Qi et al., 2018).

The studies included did not distinguish between norovirus genogroups, but it may have an impact on the intensity of transmission or the severity of the disease (Bull et al. 2010, Desai et al. 2012). In this perspective and due to the emergence of a new GII.4 variant in 2002, studying a period effect would have been relevant. However, the small number of papers and the heterogeneous distribution of publications/ORs before and after 2000 did not allow this analysis to be carried out. Further analysis by genogroup, as it was investigated for outbreaks (Matthews et al., 2012), distinguishing risk factor by genogroup, though highly interesting was not feasible in this meta-analysis. Neither could geographical differences in risk factors be studied.

Future case-control studies should investigate more precisely the exposure to drinking water with different treatment, seafood categories, food-handled, and plant products (e.g., leafy greens, soft fruits) as well as practices, such as food-handling, cooking or washing produce, in relation with duration or frequency of exposure. Making an overall grid of risk factors and transmission pathways by network analysis and prioritizing them based on biological plausibility, outbreaks reported association, the management or recommendation possibilities (Bosch et al., 2018; Guix et al., 2019) and percentage of potential exposure may be a good start. Besides, such a study would make it possible to better characterize populations considered sensitive (immunocompromised, children, the elderly) or places particularly at risk (health facilities, public transit, schools/daycare centers, communities, contact with the environment).. Finally, such studies could focus on person-to-person transmission, in relation to hygiene factors and transfers of microorganisms.

\section{Conclusion}

This meta-analysis in sporadic cases confirms the factors associated with the feco-oral pathway of transmission and factors associated with outbreaks studies (person-to-person, untreated water, seafood).

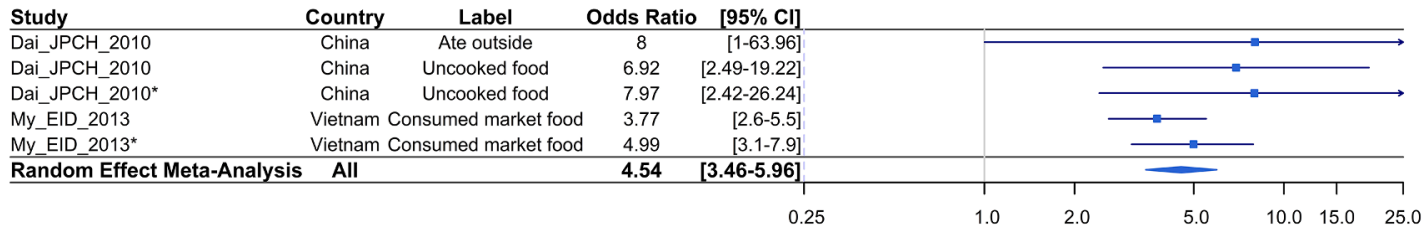

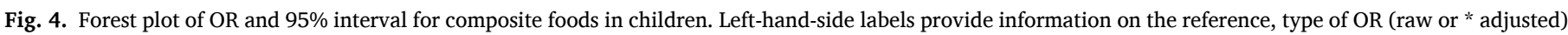
and the exposure as mentioned in the reference. 


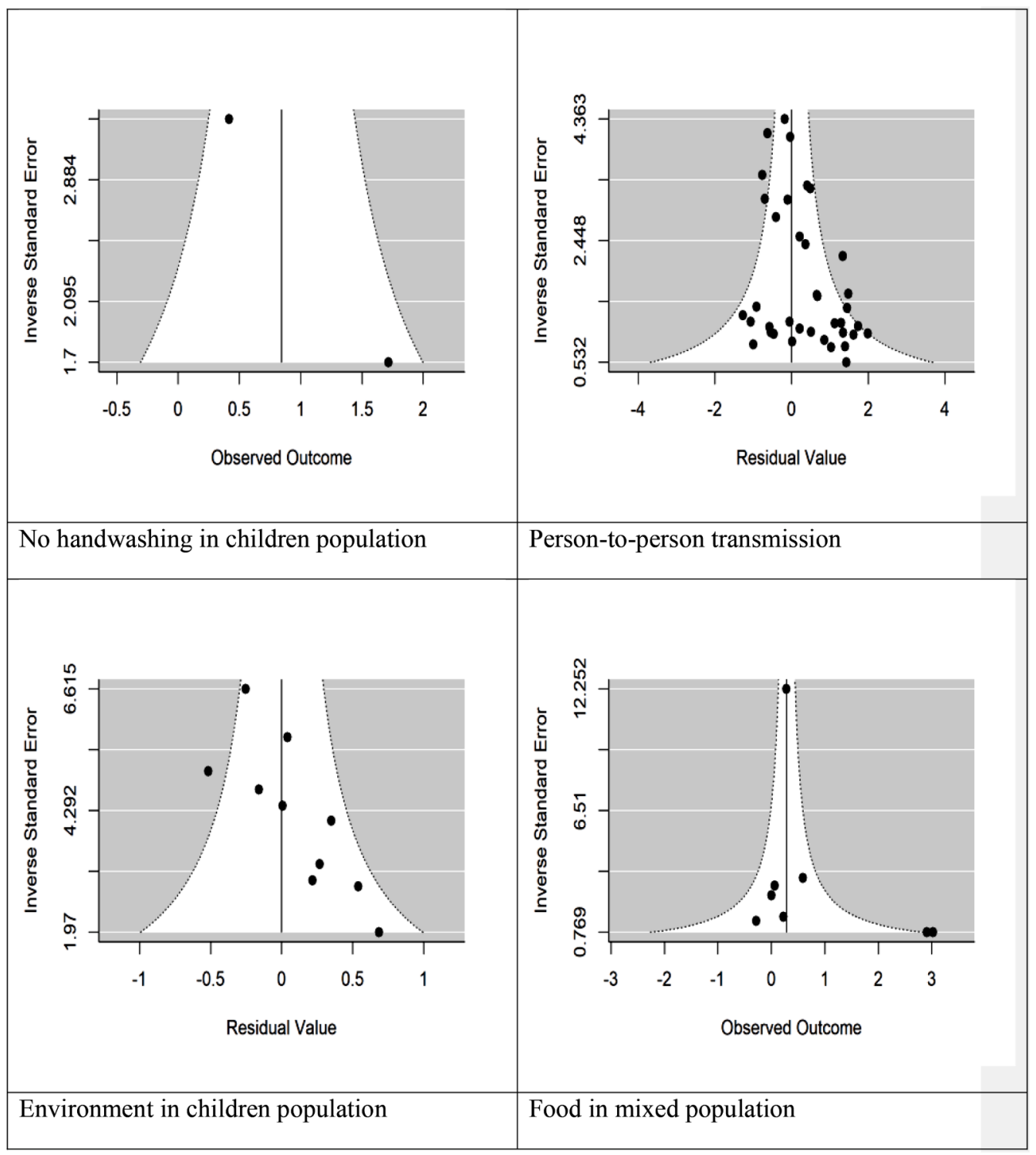

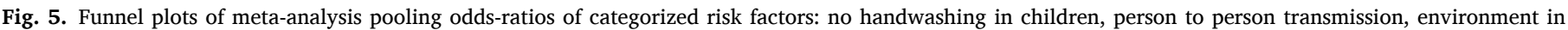

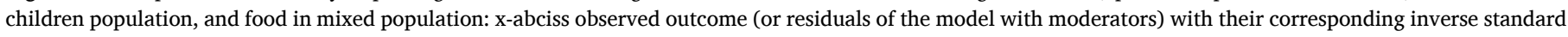
error in y-axis (Gonzales-Barron et al., 2019).

However, due to the lack of studies focusing on sporadic cases, precise risk factors could not be investigated, or were studied with a very low number of publications ( 2 or 3 sometimes). This low number of eligible studies doesn't reflect the high disease burden of norovirus.

It could be of interest to encourage specific investigation with norovirus sporadic gastroenteritis cases (case/control, cohort or crosssectional studies). So that in future, with a higher number of investigation results, it would be feasible to efficiently explore the pertinent risk factors in relationship with genogroup or genotypes, type of populations, and geographical areas at regional scale.

\section{CRediT authorship contribution statement}

Anne Thébault: Methodology, Formal analysis, Writing - original draft, Writing - review \& editing. Julie David: Writing - review \& editing. Pauline Kooh: Methodology, Project administration, Writing review \& editing. Vasco Cadavez: Methodology, Investigation, Formal analysis. Ursula Gonzales-Barron: Methodology, Investigation, Formal analysis, Writing - review \& editing. Nicole Pavio: Supervision, Writing - review \& editing.

\section{Declaration of Competing Interest}

The authors declare that they have no known competing financial interests or personal relationships that could have appeared to influence the work reported in this paper.

\section{Acknowledgments}

U. Gonzales-Barron and V. Cadavez are grateful to the Foundation for Food Science and Technology (FCT, Portugal) and FEDER under Programme PT2020 for financial support to CIMO (UID/AGR/00690/ 2019). U. Gonzales-Barron thanks the national funding by FCT, P.I., through the Institutional Scientific Employment Program contract.

The authors would like to thank ANSES staff and the members of the ANSES Working Group on Source Attribution of Foodborne Diseases: Moez Sanaa, Laurence Watier, Jean Christophe Augustin, Frédéric Carlin, Philippe Fravalo, Laurent Guillier, Nathalie Jourdan-Da Silva, Alexandre Leclercq, Lapo Mughini-Gras, Isabelle Villena. The authors would also like to thank Soizik Le Guyader for her useful comments. 


\section{References}

Ahmed, S.M., Hall, A.J., Robinson, A.E., Verhoef, L., Premkumar, P., Parashar, U.D., Koopmans, M., Lopman, B.A., 2014. Global prevalence of norovirus in cases of gastroenteritis: a systematic review and meta-analysis. Lancet Infect. Dis. 14 (8), 725-730.

Arena, C., Amoros, J.P., Vaillant, V., Ambert-Balay, K., Chikhi-Brachet, R., Jourdan-Da Silva, N., Varesi, L., Arrighi, J., Souty, C., Blanchon, T., Falchi, A., Hanslik, T., 2014 Acute diarrhea in adults consulting a general practitioner in France during winter: incidence, clinical characteristics, management and risk factors. BMC Infect. Dis. 14 574.

Atmar, R.L., Ramani, S., Estes, M.K., 2018. Human noroviruses: recent advances in a 50year history. Curr. Opin. Infect. Dis. 31 (5), 422-432.

Bitler, E.J., Matthews, J.E., Dickey, B.W., Eisenberg, J.N., Leon, J.S., 2013. Norovirus outbreaks: a systematic review of commonly implicated transmission routes and vehicles. Epidemiol. Infect. 141 (8), 1563-1571.

Boccia, D., Tozzi, A.E., Cotter, B., Rizzo, C., Russo, T., Buttinelli, G., Caprioli, A. Marziano, M.L., Ruggeri, F.M., 2002. Waterborne outbreak of Norwalk-like virus gastroenteritis at a tourist resort, Italy. Emerg. Infect. Dis. 8 (6), 563-568.

Bosch, A., Gkogka, E., Le Guyader, F.S., Loisy-Hamon, F., Lee, A., van Lieshout, L., Marthi, B., Myrmel, M., Sansom, A., Schultz, A.C., Winkler, A., Zuber, S., Phister, T., 2018. Foodborne viruses: detection, risk assessment, and control options in food processing. Int. J. Food Microbiol. 285, 110-128.

Bull, R.A., Eden, J.S., Rawlinson, W.D., White, P.A., 2010. Rapid evolution of pandemic noroviruses of the GII.4 lineage. PLoS Pathog. 6 (3), e1000831.

Chhabra, P., de Graaf, M., Parra, G.I., Chan, M.C., Green, K., Martella, V., Wang, Q., White, P.A., Katayama, K., Vennema, H., Koopmans, M., Vinjé, J., 2019. Updated classification of norovirus genogroups and genotypes. J. Gen. Virol. 100 (10), 1393-1406. https://doi.org/10.1099/jgv.0.001318.

Chan, M.C., Cheung, S.K.C., Mohammad, K.N., Chan, J.C.M., Estes, M.K., Chan, P.K.S., 2019. Use of human intestinal enteroids to detect human norovirus infectivity. Emerg. Infect. Dis. 25 (9), 1730-1735.

Dai, Y.-C., Xia, M., Zhan, H.-C., Liu, Y., Li, J.-D., Chen, Q., Yu, S.-Y., Nie, J., Farkas, T. Jiang, X., 2010. Surveillance and risk factors of norovirus gastroenteritis among children in a southern city of China in the fall-winter seasons of 2003-2006. J. Paediatr. Child Health 46 (1-2), 45-50.

De Graaf, M., van Beek, J., Koopmans, M., 2016. Human norovirus transmission and evolution in a changing world. Nat. Rev. Microbiol. 14, 421-433. https://doi.org/ 10.1038/nrmicro.2016.48.

Desai, R., Hembree, C.D., Handel, A., Matthews, J.E., Dickey, B.W., McDonald, S., Hall, A.J., Parashar, U.D., Leon, J.S., Lopman, B., 2012. Severe outcomes are associated with genogroup 2 genotype 4 norovirus outbreaks: a systematic literature review. Clin. Infect. Dis. 55 (2), 189-193.

De Wit, M.A., Koopmans, M.P., van Duynhoven, Y.T., 2003. Risk factors for norovirus, Sapporo-like virus, and group A rotavirus gastroenteritis. Emerg. Infect. Dis. 9 (12), 1563-1570.

De Wit, M.A., Widdowson, M.A., Vennema, H., de Bruin, E., Fernandes, T., Koopmans, M., 2007. Large outbreak of norovirus: the baker who should have known better. J. Infect. 55 (2), 188-193.

Dingle, K.E., 2004. Mutation in a Lordsdale norovirus epidemic strain as a potential indicator of transmission routes. J. Clin. Microbiol. 42 (9), 3950-3957.

Enserink, R., Mughini-Gras, L., Duizer, E., Kortbeek, T., Van Pelt, W., 2015. Risk factors for gastroenteritis in child day care. Epidemiol. Infect. 143 (13), 2707-2720.

Fretz, R., Svoboda, P., Schorr, D., Tanner, M., Baumgartner, A., 2005. Risk factors for infections with Norovirus gastrointestinal illness in Switzerland. Eur. J. Clin. Microbiol. Infect. Dis. 24 (4), 256-261.

Gonzales-Barron, U., Thébault, A., Kooh, P., Watier, L., Sanaa, M., Cadavez, V., 2019. Strategy for systematic review of observational studies and meta-analysis modelling of risk factors for sporadic foodborne diseases. Microb. Risk Anal., 100082

Green, K.Y., 2014. Norovirus infection in immunocompromised hosts. Clin. Microbiol. Infect. 20 (8), 717-723

Grant, L., Vinje, J., Parashar, U., Watt, J., Reid, R., Weatherholtz, R., Santosham, M., Gentsch, J., O'Brien, K., 2012. Epidemiologic and clinical features of other enteric viruses associated with acute gastroenteritis in American Indian infants. J. Pediatr. 161 (1), 110

Guix, S., Pinto, R.M., Bosch, A., 2019. Final consumer options to control and prevent foodborne norovirus infections. Viruses 11 (4).

Hardstaff, J.L., Clough, H.E., Lutje, V., McIntyre, K.M., Harris, J.P., Garner, P. O'Brien, S.J., 2018. Foodborne and food-handler norovirus outbreaks: a systematic review. Foodborne Pathog. Dis. 15 (10), 589-597.

Henke-Gendo, C., Harste, G., Juergens-Saathoff, B., Mattner, F., Deppe, H., Heim, A., 2009. New real-time PCR detects prolonged norovirus excretion in highly immunosuppressed patients and children. J. Clin. Microbiol. 47 (9), 2855-2862.

Heusinkveld, M., Mughini-Gras, L., Pijnacker, R., Vennema, H., Scholts, R., van Huisstede-Vlaanderen, K., Kortbeek, T., Kooistra-Smid, M., van Pelt, W., 2016. Potential causative agents of acute gastroenteritis in households with preschool children: prevalence, risk factors, clinical relevance and household transmission. Eur. J. Clin. Microbiol. Infect. Dis. 35 (10), 1691-1700.

Ho, MS, Glass, RI, Monroe, SS, Madore, HP, Stine, S, Pinsky, PF, et al., 1989. Viral gastroenteritis aboard a cruise ship. Lancet 2 (8669), 961-965.

Hoebe, C.J., Vennema, H., de Roda Husman, A.M., van Duynhoven, Y.T., 2004. Norovirus outbreak among primary schoolchildren who had played in a recreationa water fountain. J. Infect. Dis. 189 (4), 699-705.

Karst, S.M., 2010. Pathogenesis of noroviruses, emerging RNA viruses. Viruses 2 (3), 748-781.
Karsten, C., Baumgarte, S., Friedrich, A., Von Eiff, C., Becker, K., Wosniok, W., Ammon, A., Bockemühl, J., Karch, H., Huppertz, H.-I., 2009. Incidence and risk factors for community-acquired acute gastroenteritis in north-west Germany in 2004. Eur. J. Clin. Microbiol. Infect. Dis. 28 (8), 935-943.

Le Guyader, FS, Mittelholzer, C, Haugarreau, L, Hedlund, K-O, Alsterlund, R, Pommepuy, M, et al., 2004. Detection of noroviruses in raspberries associated with a gastroenteritis outbreak. Int. J. Food Microbiol. 97, 179-186.

Le Guyader, F.S., Krol, J., Ambert-Balay, K., Ruvoen-Clouet, N., Desaubliaux, B. Parnaudeau, S., Le Saux, J.C., Ponge, A., Pothier, P., Atmar, R.L., Le Pendu, J., 2010. Comprehensive analysis of a norovirus-associated gastroenteritis outbreak, from the environment to the consumer. J. Clin. Microbiol. 48 (3), 915-920.

Lindesmith, L.C., Donaldson, E.F., Lobue, A.D., Cannon, J.L., Zheng, D.P., Vinje, J., Baric, R.S., 2008. Mechanisms of GII.4 norovirus persistence in human populations. PLoS Med. 5 (2), e31.

Loury, P., Le Guyader, F.S., Le Saux, J.C., Ambert-Balay, K., Parrot, P., Hubert, B., 2015. A norovirus oyster-related outbreak in a nursing home in France, January 2012 Epidemiol. Infect. 143 (12), 2486-2493.

Lowther, J.A., Gustar, N.E., Powell, A.L., Hartnell, R.E., Lees, D.N., 2012. Two-year systematic study to assess norovirus contamination in oysters from commercial harvesting areas in the United Kingdom. Appl. Environ. Microbiol. 78 (16), 5812-5817.

Maalouf, H., Pommepuy, M., Le Guyader, F.S., 2010. Environmental conditions leading to shellfish contamination and related outbreaks. Food Environ. Virol. 2 (3), $136-145$.

Made, D., Trubner, K., Neubert, E., Hohne, M., Johne, R., 2013. Detection and typing of norovirus from frozen strawberries involved in a large-scale gastroenteritis outbreak in Germany. Food Environ. Virol. 5 (3), 162-168.

Manuel, C.S., Moore, M.D., Jaykus, L.A., 2018. Predicting human norovirus infectivity recent advances and continued challenges. Food Microbiol. 76, 337-345.

Matthews, J.E., Dickey, B.W., Miller, R.D., Felzer, J.R., Dawson, B.P., Lee, A.S., Rocks, J. J., Kiel, J., Montes, J.S., Moe, C.L., Eisenberg, J.N.S., Leon, J.S., 2012. The epidemiology of published norovirus outbreaks: a review of risk factors associated with attack rate and genogroup. Epidemiol. Infect. 140, 1161-1172.

Mead, P.S., Slutsker, L., Dietz, V., McCaig, L.F., Bresee, J.S., Shapiro, C., Griffin, P.M., Tauxe, R.V., 1999. Food-related illness and death in the United States. Emerg. Infect. Dis. 5 (5), 607-625.

Mounts, AW, Ando, T, Koopmans, M, Bresee, JS, Noel, J, Glass, RI, 2000. Cold weather seasonality of gastroenteritis associated with Norwalk-like viruses. J. Infect. Dis. 181 (Suppl. 2). S284-7.23.

Muller, L., Rasmussen, L.D., Jensen, T., Schultz, A.C., Kjelso, C., Barnadas, C., Sigsgaard, K., Larsen, A.R., Widstrup Jensen, C., Jeppesen, S., Uhrbrand, K., Hove, N., Molbak, K., Ethelberg, S., 2016. Series of norovirus outbreaks caused by consumption of green coral lettuce, Denmark, April 2016. PLoS Curr. 8.

My, P.V.T., Thompson, C., Phuc, H.L., Tuyet, P.T.N., Vinh, H., Hoang, N.V.M., Minh, P. V., Vinh, N.T., Thuy, C.T., Nga, T.T.T., Hau, N.T.T., Campbell, J., Chinh, N.T., Thuong, T.C., Tuan, H.M., Farrar, J., Baker, S., 2013. Endemic norovirus infections in children, Ho Chi Minh City, Vietnam, 2009-2010. Emerg. Infect. Dis. 19 (6), 977-980.

Patel, M.M., Hall, A.J., Vinje, J., Parashar, U.D., 2009. Noroviruses: a comprehensive review. J. Clin. Virol. 44 (1), 1-8.

Peasey, A., Ruiz-Palacios, G., Quigley, M., Newsholme, W., Martinez, J., Rosales, G., Jiang, X., Blumenthal, U., 2004. Seroepidemiology and risk factors for sporadic norovirus/Mexico strain. J. Infect. Dis. 189 (11), 2027-2036.

Phillips, G., Tam, C.C., Rodrigues, L.C., Lopman, B., 2010a. Risk factors for symptomatic and asymptomatic norovirus infection in the community. Epidemiol. Infect. 139 (11), 1676-1686

Phillips, G., Tam, C.C., Conti, S., Rodrigues, L.C., Brown, D., Iturriza-Gomara, M. Gray, J., Lopman, B., 2010b. Community incidence of norovirus-associated infectious intestinal disease in England: improved estimates using viral load for norovirus diagnosis. Am. J. Epidemiol. 171 (9), 1014-1022.

Polo, D., Schaeffer, J., Fournet, N., Le Saux, J.C., Parnaudeau, S., McLeod, C., Le Guyader, F.S., 2016. Digital PCR for quantifying norovirus in oysters implicated in outbreaks, France. Emerg. Infect. Dis. 22 (12), 2189-2191.

Qi, R., Huang, Y.T., Liu, J.W., Sun, Y., Sun, X.F., Han, H.J., Qin, X.R., Zhao, M., Wang, L. J., Li, W., Li, J.H., Chen, C., Yu, X.J., 2018. Global prevalence of asymptomatic norovirus infection: a meta-analysis. EClinicalMedicine 2-3, 50-58.

R development Core Team, 2008. In: R: A language and environment for Statistical Computing. R foundation for Statistical Computing, Vienna, Austria. http://www. R-project.org.

Relić, T., Begović-Lazarević, I., Pavlović, N., Ilić, N., Kačarević, H., Jovanović, D. Kostić, G., Lazarević, I., 2015. Characteristics of norovirus infection in Serbia. Vojnosanit. Pregl. 72 (4), 328-333.

Schaeffer, J., Le Saux, J.C., Lora, M., Atmar, R.L., Le Guyader, F.S., 2013. Norovirus contamination on French marketed oysters. Int. J. Food Microbiol. 166 (2), 244-248.

Sukhrie, F.H., Teunis, P., Vennema, H., Copra, C., Thijs Beersma, M.F., Bogerman, J., Koopmans, M., 2012. Nosocomial transmission of norovirus is mainly caused by symptomatic cases. Clin. Infect. Dis. 54 (7), 931-937.

Tang, M.-B., Chen, C.-H., Chen, S.-C., Chou, Y.-C., Yu, C.-P., 2013. Epidemiological and molecular analysis of human norovirus infections in Taiwan during 2011 and 2012. BMC Infect. Dis. 13 (1).

Tavoschi, L., Severi, E., Niskanen, T., Boelaert, F., Rizzi, V., Liebana, E., Gomes Dias, J., Nichols, G., Takkinen, J., Coulombier, D., 2015. Food-borne diseases associated with frozen berries consumption: a historical perspective, European Union, 1983 to 2013. Euro Surveill. 20 (29), 21193 
Verhoef, L., Koopmans, M., VAN Pelt, W., Duizer, E., Haagsma, J., Werber, D., VAN Asten, L., Havelaar, A., 2013. The estimated disease burden of norovirus in The Netherlands. Epidemiol. Infect. 141 (3), 496-506.

Verhoef, L., Hewitt, J., Barclay, L., Ahmed, S.M., Lake, R., Hall, A.J., Lopman, B., Kroneman, A., Vennema, H., Vinje, J., Koopmans, M., 2015. Norovirus genotype profiles associated with foodborne transmission, 1999-2012. Emerg. Infect. Dis. 21 (4), 592-599.

Xue, Y., Pan, H., Hu, J., Wu, H., Li, J., Xiao, W., Zhang, X., Yuan, Z., Wu, F., 2015. Epidemiology of norovirus infections among diarrhea outpatients in a diarrhea surveillance system in Shanghai, China: a cross-sectional study. BMC Infect. Dis. 15 (1). 